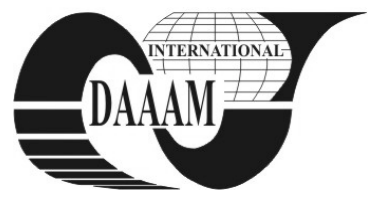

Annals of DAAAM for 2011 \& Proceedings of the 22nd International DAAAM Symposium, Volume 22, No. 1, ISSN 1726-9679 ISBN 978-3-901509-83-4, Editor B. Katalinic, Published by DAAAM International, Vienna, Austria, EU, 2011 Make Harmony between Technology and Nature, and Your Mind will Fly Free as a Bird Annals \& Proceedings of DAAAM International 2011

\title{
A DYNAMIC ANALYSIS OF INNER BEARING BUSH FROM BLADE ADJUSTMENT MECHANISM OF KAPLAN TURBINES
}

\author{
JIANU, C[amelia]; CAMPIAN, C[onstantin] V[iorel]; RIGOU, V[eronica]; SZABOLCS, S[zavai] \& IUHASZ, \\ D[aniel]
}

\begin{abstract}
This paper presents the analysis using the finite element method of an inner bearing bush from a Kaplan turbine. Motion generated by the servomotor is transmitted from the fork head through the connecting rod to the pin levertrunnion - blade subassembly. This subassembly is borne on the hub by an outer bush and an inner one. Analysis of Kaplan turbine's bushing was made in order to determine stresses distribution and displacements. A $3 D$ model of the Kaplan turbine runner was generated based on the design data.

Key words: analysis, bearing bush, finite element method, hydrodynamic load, Kaplan turbine
\end{abstract}

\section{INTRODUCTION}

The increase of renewable energy use is a global trend due to pollution generated by the conventional energy sources.

Hydroelectric energy is the most common of the renewable energy types.

There are two different types of turbines in hydropower plants: reaction turbines (Francis, Kaplan) and impulse turbines (Pelton). The rotor of Francis and Pelton turbines has fixed blades. The rotor of a Kaplan turbine has adjustable blades; the blades may change the tilt angles. This feature allows achievement of high efficiency in different conditions of the water flow.

The technical characteristics of analyzed turbine are:

- nominal speed $\mathrm{n}=71.43 \mathrm{rot} / \mathrm{min}$;

- calculus net head $\mathrm{H}_{\mathrm{c}}=26.5 \mathrm{~m}$;

- maximal power for net head $\mathrm{P}_{\max }=194 \mathrm{MW}$.

The calculations for the blade include the following steps:

- 3D solid modeling of the runner blade mechanism of the Kaplan turbine, using SolidWorks software;

- determination of blade loads from hydrodynamic conditions;

- linear static analysis.

Finite elements analysis (FEA) is a widely accepted computer simulation methodology for modeling, evaluating and optimizing a product's mechanical and structural design from a vast array of engineering fields (Kurowski, 2004; Manescu \& Nedelcu, 2005). Using FEA one is able to reduce the design time as well as expenses that come with extensive physical prototyping. Recent developments in computer hardware, numerical solutions and design optimization software are providing faster and cheaper results in an optimal design process (Nedelcu et al., 2004). Motion simulation software gives the reaction forces/moments acting on each component. The reactions and the body forces acting on each component can be exported to finite element analysis studies in order to determine stress distribution.

A Kaplan turbine runner must be designed according to an optimal cost-efficiency and long-term productive life for coping with the evolution of industrial technology, materials, energy sources and environmental regulations.

While functioning, failures can occur due to high loads or the fatigue phenomenon (Lange, 2001).
Studies regarding failure of different parts of Kaplan turbines were made: runner blade (Campian et al., 2008; Frunzaverde et al., 2010), pin lever (Pittner, 2010), but not on the bushing mechanism.

The objective of this paper is to analyze, using finite element method (FEM) and motion analysis, the dynamical behavior of the bushing adjustment mechanism of Kaplan turbines. The motion generated by the servomotor is transmitted from the fork head through the connecting rod to the pin lever - trunnion - blade subassembly.

This subassembly of Kaplan turbine is supported on the hub by two bushings: an outer bush and an inner one. Analysis of Kaplan the turbine's bushing was made in order to determine stresses distribution and displacements.

\section{3D GEOMETRY}

The link-fork head-piston assembly of Kaplan turbine has a complex 3D geometry, as shown in figure 1, which must be generated using adequate CAD software for final drawing and for finite element strength calculus. As CAD software it has been chosen SolidWorks (Jianu, 2010; Jianu et al., 2010).



Fig. 1. The outer and the inner bearing bush

\section{HYDRODYNAMIC LOADS OF THE MECHANISM}

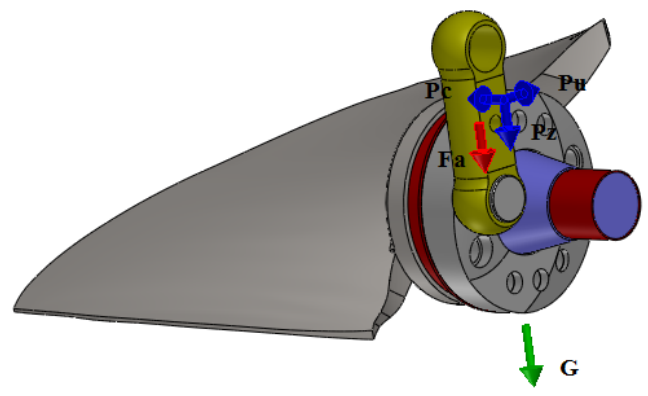

Fig. 2. Hydrodynamic loads applied on runner 
The hydrodynamic loads applied on the axial runner are presented in figure 2:

- gravity load $G$;

- centrifugal force $P_{c}$ for the runner speed $71.43 \mathrm{rot} / \mathrm{min}$;

- axial thrust $P_{z}$, resulted from measurements on model;

- tangential force $P_{u}$;

- $P$ is the resultant of hydraulic force acting on blade;

- $F_{a}$ is the load acting on the blades

\section{RESULTS OF ANALYSIS OF INNER BEARING BUSH}

The inner bearing bush was studied using SolidWorks software, which offers a wide range of advanced type analysis options. The software offers different solvers to handle different types and sizes of problems more efficiently.

Finite elements analysis was performed using SolidWorks Simulation software and motion analysis was performed using SolidWorks Motion. For the motion study, loads are applied on the surfaces of fork head and blade. The results of simulations considered for inner bearing bush are shown in table 1 .

\begin{tabular}{|c|c|c|l|c|}
\hline Name & Type & Min & Max & Location \\
\hline Stress & von & 1.68663 & 105.67 & 0.633284 \\
& Mises & $(\mathrm{MPa})$ & $(\mathrm{MPa})$ & 0 \\
& & & & 0.342567 \\
& & & & $(\mathrm{~m})$ \\
\hline Displace- & URES & 0 & 0.0504232 & 0.595124 \\
ment & & $(\mathrm{mm})$ & $(\mathrm{mm})$ & 0.209958 \\
& & & & -0.366591 \\
& & & & $(\mathrm{~m})$ \\
\hline
\end{tabular}

Tab.1. Numerical results for stress distribution



Fig. 3. Stress distribution of inner bearing bush

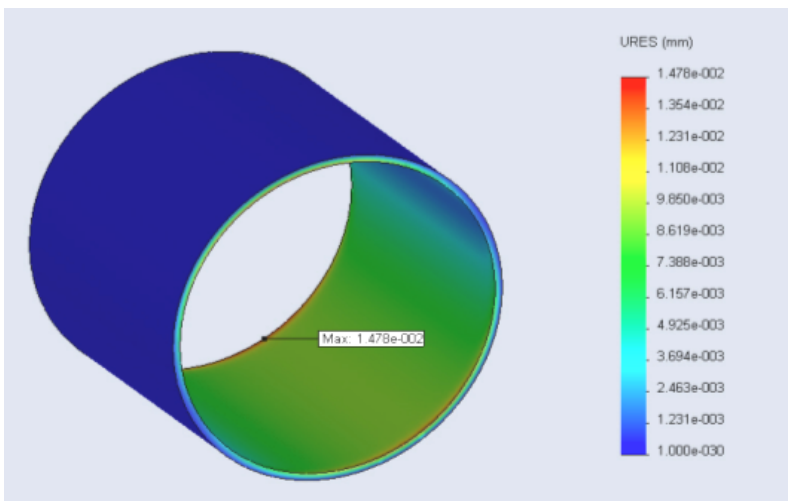

Fig. 4. Resultant displacement of inner bearing bush

Stress distribution obtained for the inner bearing bush can be observed in figure 3, as well as displacements resulted from simulations can be seen in figure 4 . The maximum value of the Von Mises stress is $105,67 \mathrm{MPa}$, lower than yield strength of $110,3 \mathrm{MPa}$
Results predicted using finite element method show that this method is efficient and accurate and in good agreement with the theoretical and experimental values.

\section{CONCLUSION}

The analysis of inner bearing bush was made to determine stress distribution and displacement.

A complex geometry three-dimensional model of the inner bearing bush was generated based on the designed data.

Results from the current analysis can be used for further studies in design of Kaplan turbine runners as part of a continuous product development process.

As further research, a fatigue analysis of inner bearing bush can be made. Together with the current results, it will make a complete suite of analyses which validates the bearing bush for usage in new Kaplan turbines.

Added to this, the current paper can serve as a guide for research based on parts containing the bushing.

\section{REFERENCES}

Campian C.V., Frunzaverde, D., Nedelcu, D., Marginean G., (2008). Failure Analysis of a Kaplan Turbine Runner Blade, Proceedings of 24th IAHR Symposium on Hydraulic Machinery and Systems, 27-31st October 2008, Foz do Iguassu, Brazil, ISBN 978-85-60858-13-1, pp. 1-10

Frunzaverde D., Campian V., Nedelcu D., Gillich G.-R., Marginean G., (2010). Failure Analysis of a Kaplan Turbine Runner Blade by Metallographic and Numerical Methods, Proceedings of 5th IASME/WSEAS International Conference on Continuum Mechanics/7th WSEAS International Conference on Fluid Mechanics, 23-25th February 2010, Cambridge, England, ISSN: 1790-5095, ISBN: 978-960-474-158-8, pp. 60-66, WSEAS Press

Jianu C., (2010). "Computer Aided Design of Kaplan Turbine piston with SolidWorks”, Analele Universitatii „Eftimie Murgu” - Fascicula de Inginerie, Resita, XVII, Nr.2, 2010, pp 155-164, ISSN 1453-7397

Jianu C., Budai A.M., Campian C.V., (2010). "Computer Aided Design of the link-fork head-piston assembly of the Kaplan turbine with Solidworks" Analele Universitatii „Eftimie Murgu” - Fascicula de Inginerie, Resita, XVII, Nr.2, 2010, pp 165-174, ISSN 1453-7397

Kurowski P.M. (2004). Finite Element Analysis for Design Engineers, Publisher SAE International, ISBN 978-0-76801140-1, Warrendale, PA

Lange G., (2001). Systematische Beurteilung technischer Schadensfälle, 5.Auflage, Wiley-VCH Verlag, D-69469, ISBN 3-527-30417-7, Weinheim, Germany

Manescu T., Nedelcu D., (2005). Structural analysis by finite element method, (Analiza structurala prin metoda elementului finit), Editura „Orizonturi Universitare”, ISBN 973-638-217-6, Timisoara

Nedelcu D., Manescu T. St., Campian C. V., (2004). Finite Element Through COSMOS M/Design STAR, FME Transactions, Vol. 32, No. 1, 2004, University of Belgrade, ISSN 1451-2092

Pittner A.-M., Campian, C.V., Nedelcu D., Frunzaverde D., Cojocaru V., (2010). Stress Concentration Factors for Pin Lever of Runner Blade Mechanism from Kaplan Turbines, Proceedings of 3rd WSEAS International Conference on Engineering Mechanics, Structures, Engineering Geology (EMESEG '10), 22-24th July 2010, Corfu Island, Greece, ISSN: 1792-4294, ISBN: 978-960-474-203-5, pp. 181-185, WSEAS Press. 